suppressed by this close association until activated by the ultra-violet light. In work undertaken in co-oporation with the National Institutes of Health the technique has shown thet tumours in rodent species contain polynucleotide sequences that aro complomontary to those of the polyome virus DNA, thus demonstrating the presence of cancer virus in material in the host it has infoctod.

In the Department of Embryology tho yoar was marked by the isolation and characterization of DNA from the eggs of Rana pipiens and Xenopus laevis. In addition to a large pool of solublo compounds containing dooxyribose, those oggs contain 100-300 times the amount of DNA, of high molecular weight resembling that from liver of the samo specios, found in somatic cells of these species. Nucloic acid synthesis in the anucleolate mutant of Xenopus laevis was also described, and a series of investigations was commenced on the synthesis of messenger RNA in Xenopus laevis, using the agar-DNA technique, in which the 12NA is isolated by hydridizing with DNA immobilized in an inert agar matrix; investigations of the heterogeneous inductors from chick embryo were also continued. Evidonce was accumulated boaring on the hypothesis that trypan blue acts by binding lysosomal enzymes involved in yolk utilization in the chick ombryo, and the effects of thalidomide dorivatives on the chick embryo wore also oxamined. Observations of the movement of clusters of precirdiac cells in chick ombryos wore extended.

In tho Gonotics Research Unit, investigations on gene regulation in maize were concerned with the control system regulating the somatic oxpression of the genos. These also included the parameters of the regulation of gene action by the suppressor-mutation systern and cyclical change in the phuse of activity of the activator, and the relation botween DNA structure and chromosomal function in which some idiosyncrasies of phage DNA structure were elucidated.

The Dopartment of Plant Biology's Photosynthesis Group was chiefly concerned with the changes induced in the state of those substaneos presumed to be intermediates in the process of photosynthesis when plants are illum- inated, and with the changes in rates of evolution of oxygon or uptake caused by varying exposures to light. Tho pigment complexes of the photochomical system are now accepted as falling into two groups. The first is a system composod mainly of a long wave-length of chlorophyll $a$ absorbing red wave-lengths, which soems to act by passing its light enorgy to a substance known as $P 700$, probably another form of chlorophyll $a$. The socond is composed mainly of a group of 'accessory' pigments which absorb light at shorter wave-lengths, the end of energy transfer procoss being chlorophyll $\alpha 673$, also a redabsorbing pigment. The experiments in progross were designed to provide the basis for models of parts of the complete system. During the year experiments with light exposure in the red and far-red wave-longths and measurements of changes in the light absorption of plastocyenin in the colls showed that plastocyanin has a place in the photosynthetic system related to both pigment systemsthe first system oxidizing it in the living chloroplasts and the second system reducing it. The alga Ulva was also examined, and particular attention was directed to measuring the oxygen evolution and uptake in response? to wave-longths representing these two pigment systems : sodium dodecyl sulphate was used to separato partly the forms of chlorophyll $\alpha$ with absorption bands at 670 and $680 \mathrm{~m} \mu$. A brief survey was made of how the temporature of leaves, particularly Mimulus, is affected by different surroundings, and clear difforences were demonstrated in the response of $M$. lewisii and $M$. cardinalis to ohanges in light intensity, temperature and oarbon dioxide concentration. Work also continued on the climatic races of Solidago virgaurea, while in the Cytogenetics Laboratory an electron microscopic investigation of motabolic chromosomes of Tradescantia and of the polytone chromo. somos of the salivary-gland cells of Drosophila were undertaken. A cytochemical analysis was carried out on the busic proteins of chromosomos and cells in early ombryogenesis in Drosophila. Other investigations included autoradiographic analysis of tho incorporation of tritiated precursors of DNA, RNA and basic proteins in the giant salivary-gland chromosomes of Drosophila, and a chemical analysis of the nucleic acids of Drosophila.

\title{
DEVELOPMENT OF HIGHER EDUCATION IN BRITAIN
}

N a statement in the House of Commons on February 24 1 on the development of highor oducation, which was also made in the House of Lords by Lord Bowden, the Secretary of State for Education and Science, Mr. A. Crosland, said that the Government had now considored the recommendations of the Robbins Committee for the expansion of teacher-training places, the creation of new universities, and the designation of Special Institutions for Suientific and Technological Education and Resoarch. The Government accepted the objectives of 390,000 fulltime places in higher education by $1973-74$, including 218,000 places in universitios, and had decided that 122,000 of tho romining places should be places for training tonchors. This would nearly double the number of studenls in training, but all possible ways of incroasing the output of tenchers from existing facilities were also boing urgently examined. Ho was keoping the supply of teachers under close reviow and anticipated recoiving shortly the next report of the National Advisory Council on tho Training and Supply of Teachors. On now univer. sitios, Mr. Crosland said that it was now clear that tho 218,000 university places were within the capacity of existing universities and other institutions of university status. The colleges of advanced technology and the Heriot Watt College would bo given university status, and tho University Grants Committee would bo advising the Government on the means by which the Royal College of Art and the Colloge of Aoronautics, Cranfield, eould also be brought within the Committee's ambit. Apart from these plans and the creation of separate universities at St. Androws and Dundec, tho Govermment had decided that, with tho possible exception of creating an entircly now technological university institution in the North-East, no additional universitios wonld be needed for about ton years; however, the possibility would be examined well within that period that moro would be nocded thereafter.

While wholly accopting the principle of selective devolopment and expansion of technological education at a high level, the Government considerod that this would best be achieved not by creating a separate category of spocial institutions but by continuing to build up the three institutions named by the Robbins Committee-the Imperial Collego of Science and Technology, the Manchester Collego of Science and Technology and the University of Strathelyde. These would be given priority in the provision of capital and current finance.

Roplying to questions on this statement, Mr. Crosland said that about 61,000 teachers wore now in training colleges, and under tho now plans there would be 111,000 in 1973-74. He would be disappointed if he was unable to mako a statement on short-term moasures to inerease 
the supply of teachers within the next few weeks. The universities were expanding much more quickly than anyone had expected, and the new universities set up since 1960 had also got off the ground very much earlier than had been expected. It was much less expensive to expand existing institutions than to establish new ones. No decrease was contemplated in the 50,000 places in colleges of further education recommended by the Robbins Committee. He was giving higher priority to determining the reason for the 1,500 vacant places in science and technology. The programme fell within the 4.25 per cent expansion of the public service announced by the Chancellor of the Exchequer. He hoped to make a statement within the next few weeks about the wastage of teachers and its elimination.

In making this statement in the House of Lords also on February 24, Lord Bowden said that the University
Grants Committee was considering the amounts of extra recurrent grant which were most urgently needed, and indicated that he hoped to make a statement shortly. Earlier on, in reply to a question regarding implementation of the Newsom Report, Lord Bowden had stated that the raising of the school-leaving age was now planned to come into effect in the academic year 1970-71. Full account was being taken of the Committee's other recommendations by the Department of Education and Science in its forward thinking about curricula, teacher training and design of buildings and equipment. The Schools Council for the Curriculum and Examinations was studying the new approaches to questions concerning curricula which would be required, and some research projects were already in train. The total sum to be spent on school building had increased by 25 per cent, and would be about $£ 20$ million next year.

\section{COMPUTER RESEARCH AND DEVELOPMENT IN BRITAIN}

I $\mathrm{N}$ statement on the computer industry in the House I of Commons on March 1, the Minister of Technology, Mr. F. Cousins, said that the Government considers it essential that there should be a rapid increase in the use of computers and computer techniques in industry and commerce and also a flourishing British computer industry. First, he was forming a Computer Advisory Unit within the Ministry of Technology to advise on computer requirements over the whole public sector. All proposals for computers required by Government departments for civil purposes would be referred to this Unit for objective technical appraisal before procurement was authorized; a similar procedure would apply to computers purchased with public money by universities, colleges of advanced technology and Research Councils. The advice of the Unit would be available to local authorities, nationalized industries and other users in the public sector, and the Unit would work closely with the computer industry in planning new developments. It would be based on the Technical Support Unit of the Treasury, which would be transferred to the Ministry of Teohnology and built up to about double its present size as rapidly as possible.

Secondly, the Government had initiated a full-scale review of the computer requirements of universities, colleges of advanced technology and Research Councils; the University Grants Committes and the Council for Scientific Policy were jointly assessing the new facilities needed. This review would lead to a new five-year programme of procurement which should greatly reinforce the capabilities of the universities and the Research Councils in this vital area and provide an important stimulus to the industry. The equipment needed would be procured after consultation with the Ministry of Technology. Details could not be settled until the assessment was completed in a few months' time, but the Government proposed to start this programme at the rate of $£ 2$ million a year.

Thirdly, further programmes of research on computer techniques and the development of new equipment would be initiated in industry, the universities and in Govern. ment research establishments and in the Post Office, while the National Research Development Corporation would be greatly extending its work in this field. Subject to passage of the Development of Inventions Bill, Mr. Cousins said that he had approved in principle the Corporation's proposals for assisting computer development on a substantial scale. Research into computer development techniques for the 1970's was already being sponsored in partnership with industry under the Advanced Computer Techniques Project, for which $£ 1$ million had been earmarked and which the Ministry of Technology would be taking over from the Department of Scientific and Industrial Research. Further developments under this project were being discussed and, if industry was willing to share the cost of enlarging this programme, the Government hoped to place contracts in 1965-66 involving additional Government commitments of $£ 500,000$. The Ministry hoped to place contracts with the universities in 1965-66 for industry-orientated research to the value of about $£ 500,000$ and other work at universities would be financed through the Science Research Council.

Fourthly, he was exploring with the industry and with users the possibilities of establishing a National Computer Programme Centre in which they would be partners with the Government. Such a Centre would acquire programmes from computer makers and users and form a library. It would have funds to buy existing programmes for the library and to commission new programmes required for use with British computers. Mr. Cousins believed that such a Centre would help Britain to make better use of her programming resources.

Replying to questions, Mr. Cousins confirmed that the survey of proposals to be made by the Computer Advisory Unit would be purely objective. One of the problems was the shortage of trained staff, and this was being examined jointly with the Department of Education and Science. Much attention must be directed to training skilled programmers. He thought a standard programme language would be of great value. Britain's policy was designed to make the greatest use of her resources to establish a thriving British computer industry, but any increase in orders from British industry was the responsibility of industry, not of the Minister of Technology. On March 2 he added that Britain's efforts were designed to encourage the creation of a suitable type of computer for the home market which might have export possibilities too, and to establish a situation in which computers would not be ordered from the United States simply because no suitable British computer was available. In a written answer on March 3, Mr. Cousins gave details of the research and development contracts placed by the Department of Scientific and Industrial Research under the Advanced Computer Techniques Project and the Super Conductivity Project, and of a further contract under the Advanced Computer Techniques Project, which was still under negotiation with International Computers and Tabulators, Ltd., for design automation, in which the Department of Scientific and Industrial Research would contribute half the $£ 92,000$ involved. 